\title{
PENDIDIKAN KESEHATAN GIZI PADA LANSIA DAN PEMERIKSAAN KESEHATAN FISIK DI DESA TALOK KEC.TUREN KAB.MALANG
}

\author{
Subekhi Hadi Purnomo, Rita Darmayanti, Lia Agustina, R. Setiawan, Futuh Handoyo \\ rita.darmayanti@polinema.ac.id
}

\begin{abstract}
Abstrak - Tujuan utama dari dibentuknya Posyandu (Pos Pelayanan Terpadu) di Indonesia adalah sebagai salah satu upaya pembangunan nasional yang tercermin dalam Indeks Pembangunan Manuasia (IPM) yang terdiri dari umur harapan hidup, tingkat melek huruf dan pendapatan per kapita. Posyandu adalah salah satu usaha kesehatan yang bersumberdaya masyarakat (UKBM) yang melibatkan kader yang sudah dipilih dan ditunjuk oleh masyarakat sehingga posyandu bisa dikatakan miliknya masyarakat. Posyandu Lansia Desa Talok dipilih debagai mitra dalam PKM ini karena jumlah lansia di lingkungan posyandu ini cukup tinggi yakni kurang lebih 70 orang dengan tingkat pengetahuan gizi dan kesehatan yang masih perlu ditingkatkan. Sebagian besar para lansia di area ini adalah ibu rumah tangga dengan latar belakang belakang pendidikan SD sampai SMA, namun pengetahuan mereka tentang gizi serta pola makan dan pola hidup yang baik masih minim. Di sisi lain, posyandu ini, sebagaimana posyandu pada umumnya, hanya memfokuskan pada memantau aspek kesehatan fisik lansia dimana tingkat partisipasi lansia masih rendah. Oleh karena itu dibutuhkan penyuluhan tentang gizi pada lansia untuk meningkatkan tingkat kesehatan pada lansia. Pengabdian kepada masyarakat ini dilaksanakan dengan cara memberikan penyuluhan singkat tentang pentingnya menjaga kesehatan pad lansia terutama menjaga tekanan darah, gula darah, kolesterol dan asam urat. Lansia mengalami kemunduran dan keterbatasan maka konsistensi dan tekstur atau bentuk makanan harus disesuaikan. Mengingat kondisi dan permasalahan lanjut usia seperti diuraikan di atas, maka penanganan masalah gizi pada lanjut usia harus menjadi prioritas, karena permasalahannya terus meningkat sesuai dengan pertambahan jumlahnya. Dengan demikian penyuluhan kesehatan gizi pada lansia dan pemeriksaan fisik, penimbangan berat badan, serta pemeriksaan tekanan darah, kolesterol, asam urat dan gula darah pada lansia sangat perlukan, sesuai dengan kebutuhannya dan pada lingkungan yang tepat, sehingga para lansia tidak merasa lagi terabaikan didalam masyarakat.
\end{abstract}

Kata kunci: foodbusiness.

\section{PENDAHULUAN}

\subsection{Latar Belakang}

Menurut Pedoman Pelaksanaan Posyandu Lanjut Usia, Komisi Nasional Lanjut Usia (2010) disebutkan bahwa Pos Pelayanan Terpadu (Posyandu)
Lanjut Usia adalah suatu wadah pelayanan kepada lanjut usia di masyarakat, yang proses pembentukan dan pelaksanaannya dilakukan oleh masyarakat bersama lembaga swadaya masyarakat (LSM), lintas sektor pemerintah dan non-pemerintah, swasta, organisasi sosial dan lain-lain, dengan menitik beratkan pelayanan kesehatan pada upaya promotif dan preventif. Disamping pelayanan kesehatan, di Posyandu Lanjut Usia juga dapat diberikan pelayanan sosial, agama, pendidikan, ketrampilan, olah raga dan seni budaya serta pelayanan lain yang dibutuhkan para lanjut usia dalam rangka meningkatkan kualitas hidup melalui peningkatan kesehatan dan kesejahteraan mereka. Selain itu mereka dapat beraktifitas dan mengembangkan potensi diri.

Masa lanjut usia adalah masa dimana individu dapat merasakan kesatuan, integritas, dan refleksi dari kehidupannya. Jika tidak, ini akan menimbulkan ketimpangan dan bahkan dapatmengakibatkan patologis, semacam penyakit kejiwaan (Latifah, 2010). Lansia di Indonesia, menurut Depkomindo 2010, pada tahun 2008 berjumlah 23 juta orang, sedangkan lansia yang terlantar mencapai 1,7 juta sampai 2 juta orang. Masalah kesehatan mental pada lansia dapat berasal dari 4 aspek yaitu fisik, psikologik,sosial dan ekonomi. Masalah tersebut dapat berupa emosi labil, mudah tersinggung, gampang merasa dilecehkan, kecewa, tidak bahagia, perasaan kehilangan, dan tidak berguna. Lansia dengan masalah tersebut menjadi rentan mengalami gangguan psikiatrik seperti depresi, ansietas (kecemasan), psikosis (kegilaan) atau kecanduan obat. Pada umumnya masalah kesehatan mental lansia adalah masalah penyesuaian. Penyesuaian tersebut karena adanya perubahan dari keadaan sebelumnya (fisik masih kuat, bekerja dan berpenghasilan) menjadi kemunduran.

Menurut WHO, yang termasuk katagori lansia, adalah mereka yang berusia 65 tahun ke atas (AS dan Eropa Barat). Sedangkan di negara-negara Asia, lansia adalah mereka yang berusia 60 tahun keatas. Pengkatagorian lebih detail dikemukakan oleh Durmin dalam Arisman (2007), yang membagi lansia menjadi young elderly (65-74 tahun) dan older elderly (75 tahun). Sementara di Indonesia, M. Alwi Dahlan dalam Arisman (2007) menyatakan bahwa orang dikatakan lansia jika telah berumur di atas 60 tahun.
Sementara
Notoatmodjo
(2007)

mengemukakan, bahwa lansia merupakan tahap akhir siklus kehidupan. Lansia juga merupakan tahap perkembangan normal yang akan dialami oleh setiap individu yang mencapai usia lanjut dan merupakan kenyataan yang tidak dapat dihindari. Lansia adalah kelompok orang yang sedang mengalami suatu proses 
perubahan yang bertahap dalam jangka waktu beberapa dekade. Lansia dimulai paling tidak saat puber dan prosesnya berlangsung sampai kehidupan dewasa. Menurut Depkes RI (2000), konteks kebutuhan lansia akan dihubungkan secara biologis, sosial dan ekonomi.

Lansia juga identik dengan menurunnya daya tahan tubuh dan mengalami berbagai macam penyakit. Lansia akan memerlukan obat yang jumlah atau macamnya tergantung dari penyakit yang diderita. Semakin banyak penyakit pada lansia, semakin banyak jenis obat yang diperlukan. Banyaknya jenis obat akan menimbulkan masalah antara lain kemungkinan memerlukan ketaatan atau menimbulkan kebingungan dalam menggunakan atau cara minum obat. Disamping itu dapat meningkatkan resiko efek samping obat atau interaksi obat. Pemberian nutrisi yang baik dan cukup sangat diperlukan lansia. Hal tersebut dilakukan dengan pertimbangan bahwa lansia memerlukan nutrisi yang adekuat untuk mendukung dan mempertahankan kesehatan. Beberapa faktor yang mempengaruhi kebutuhan gizi antara lain: berkurangnya kemampuan mencerna makanan, berkurangnya cita rasa, dan faktor penyerapan makanan.

Bagi lansia pemenuhan kebutuhan gizi yang diberikan dengan baik dapat membantu dalam proses beradaptasi atau menyesuaikan diri dengan perubahanperubahan yang dialaminya selain itu dapat menjaga kelangsungan pergantian sel-sel tubuh sehingga dapat memperpanjang usia. Kebutuhan kalori pada lansia berkurang karena berkurangnya kalori dasar dari kebutuhan fisik. Kalori dasar adalah kalori yang dibutuhkan untuk malakukan kegiatan tubuh dalam keadaan istirahat, misalnya untuk jantung, usus, pernafasan dan ginjal. Gangguan gizi yang dapat muncul pada usia lanjut dapat berbentuk gizi kurang maupun gizi lebih. Gangguan ini dapat menyebabkan munculnya penyakit atau terjadi sebagi akibat adanya penyakit tertentu. Oleh karena itu langkah pertama yang harus dilakukan adalah menetukan terlebih dahulu ada tidaknya gangguan gizi, mengevaluasi faktor-faktor yang berhubungan dengan gangguan gizi serta merencakan bagaimana gangguan gizi tersebut dapat diperbaiki.

Dengan memperhatikan prinsip-prinsip kebutuhan gizinya yaitu kebutuhan energi memang lebih rendah dari pada usia dewasa muda (turun sekitar $5-10 \%)$, kebutuhan protein sebesar $1 \mathrm{gr} / \mathrm{kg} \mathrm{BB}$, kebutuhan lemak berkurang, kebutuhan karbohidrat cukup (sekitar 50\%), kebutuhan vitamin dan mineral sama dengan usia dewasa muda. Atau dengan cara praktis melihat di DKGA (Daftar Kecukupan Gizi yang Dianjurkan). Menu yang disajikan untuk lansia harus mengandung gizi yang seimbang yakni mengandung sumber zat energi, sumber zat pembangun dan sumber zat pengatur. Dalam hal ini kita bisa mengacu pada makanan empat sehat lima sempurna.

Tiga masalah utama kesehatan pada lansia yaitu tingginya kadar gula darah, tekanan darah, asam urat dan kolesterol. Diabetes melitus merupakan sekelompok kelainan heterogen yang ditandai dengan kenaikan kadar glukosa dalam darah atau hiperglikemia. Glukosa secara normal bersirkulasi dalam jumlah tertentu dalam darah. Glukosa dibentuk di hati dari makanan yang dikonsumsi. Insulin, yaitu suatu hormon yang diproduksi oleh pankreas, mengendalikan kadar glukosa dalam darah dengan mengatur produksi dan penyimpanannya.

Pada diabetes, kemampuan tubuh untuk bereaksi terhadap insulin dapat menurun, atau pankreas dapat menghentikan sama sekali produksi insulin, keadaan ini menimbulkan hiperglikemia yang dapat mengakibatkan komplikasi metabolik akut seperti diabetes ketoasidosis dan sindrom hiperglikemik hiperosmoler nonketotik (HHNK). Hiperglikemia jangka panjang dapat ikut menyebabkan komplikasi mikrovaskuler yang kronis (penyakit ginjal dan mata) dan komplikasi neuropati (penyakit pada saraf). Diabetes juga disertai dengan peningkatan insidens penyakit makrovaskuler yang mencakup infark miokard, stroke, dan penyakit vaskuler perifer.

Diabetes terutama prevalens di antara kaum lansia. Di antara individu yang berusia lebih dari 65 tahun, 8,6 \% menderita diabetes tipe II. Angka ini mencakup $15 \%$ populasi pada panti lansia. Di Amerika Serikat, diabetes merupakan penyebab utama kebutaan yang baru di antara penduduk berusia 25 hingga 74 tahun dan juga menjadi penyebab utama amputasi di luar trauma kecelakaan. $30 \%$ pasien yang mulai mendapat terapi dialisis setiap tahun menderita penyakit diabetes. Diabetes berada di urutan ke-3 penyebab utama kematian akibat penyakit dan hal ini sebagian besar disebabkan oleh angka penyakit arteri koroner yang tinggi pada para penderita diabetes melitus. (Brunner and Suddarth, 2006)

Lansia mengalami kemunduran dan keterbatasan maka konsistensi dan tekstur atau bentuk makanan harus disesuaikan. Mengingat kondisi dan permasalahan lanjut usia seperti diuraikan di atas, maka penanganan masalah gizi pada lanjut usia harus menjadi prioritas, karena permasalahannya terus meningkat sesuai dengan pertambahan jumlahnya. Dengan demikian penyuluhan kesehatan gizi pada lansia dan pemeriksaan fisik, penimbangan berat badan, serta pemantauan status gizi pada lansia sangat perlukan, sesuai dengan kebutuhannya dan pada lingkungan yang tepat, sehingga para lansia tidak merasa lagi terabaikan didalam masyarakat.

\section{TINJAUAN PUSTAKA}

Posyandu adalah pusat kegiatan masyarakat dalam upaya pelayanan kesehatan dan keluarga berencana. Kegiatan posyandu adalah perwujudan dari peran serta masyarakat dalam menjaga dan meningkatkan derajat kesehatan mereka. posyandu lansia adalah suatu forum komunikasi, alih teknologi dan pelayanan kesehatan oleh masyarakat dan untuk masyarakat yang mempunyai nilai strategis untuk pengembangan sumber daya manusia khususnya lanjut usia (Depkes, 2000). Adapun tujuan dari dibentuknya posyandu lansia menurut Azrul (1998), yaitu 
memelihara kondisi kesehatan dengan aktifitas fisik sesuai kemampuan dan aktifitas mental yang mendukung, memelihara kemandirian secara maksimal, melaksanakan diagnosa dini secara tepat dan memadai, melaksanakan pengobatan secara tepat, membina lansia dalam bidang kesehatan fisik spiritual, sebagai sarana untuk menyalurkan minat lansia, meningkatkan rasa kebersamaan diantara lansia, meningkatkan kemampuan lansia untuk mengembangkan kegiatan kesehatan dan kegiatan kegiatan lain yang menunjang sesuai dengan kebutuhan.

Menurut Depkes RI (2003), tujuan umum dibentuknya Posyandu lansia secara garis besar untuk meningkatkan derajat kesehatan dan mutu kehidupan usia lanjut untuk mencapai masa tua yang bahagia dan berdaya guna dalam kehidupan keluarga dan masyarakat sesuai dengan keberadaannya. Sedangkan tujuan khusus pembentukan posyandu lansia antara lain meningkatkan kesadaran para usia lanjut untuk membina sendiri kesehatannya, meningkatkan kemampuan dan peran serta keluarga dan mas $7 \mathrm{~m} 7$ myarakat dalam menghayati dan mengatasi kesehatan usia lanjut, meningkatkan jenis dan jangkauan pelayanan kesehatan usia lanjut, meningkatkan mutu pelayanan kesehatan usia lanjut.

Sasaran penyelenggara posyandu lansia adalah seluruh penduduk yang berusia 60 tahun keatas (Depkes,2000). Menurut Pedoman Pembinaan Kesehatan Usia Lanjut Bagi Petugas Kesehatan I Kebijaksanaan Program (Depkes RI (2000), sasaran pelaksanaan pembinaan kelompok usia lanjut dibagi menjadi dua. Pertama,sasaran Langsung, meliputi Pra lansia (usia 45 - 59 tahun), Lansia (usia 60 - 69 tahun) dan Lansia risiko tinggi (usia > 70 tahun). Kedua sasaran Tidak Langsung, antara lain a). Keluarga lansia; b). Masyarakat lingkungan lansia; c). Organisasi sosial yang peduli terhadap pembinaan kesehatan lansia; d). Petugas kesehatan yang melayani kesehatan lansia; e). Petugas lain yang menangani kelompok lansia; dan f). Masyarakat luas. Upaya Posyandu Lansia

Upaya-upaya yang dilakukan dalam posyandu lansia antara lain upaya meningkatkan / promosi kesehatan yang pada dasarnya merupakan upaya mencegah primer (primary prevention). Menurut Suyono (1997), ada beberapa tindakan yang disampaikan dalam bentuk pesan "BAHAGIA" yaitu berat badan berlebihan agar dihindari dan dikurangi, aturlah makanan hingga seimbang, hindari faktor resiko penyakit degenerative, agar terus berguna dengan mempunyai hobi yang bermanfaat, gerak badan teratur agar terus dilakukan, iman dan takwa ditingkatkan, hindari dan tangkal situasi yang menegangkan, awasi kesehatan dengan memeriksa badan secara periodic.

Gula dalam darah disebut sebagai glukosa. Glukosa berasal dari dua sumber, yaitu dari makanan yang masuk dan yang diproduksi oleh hati. Makanan sehari-hari se gula pasir, dan minuman soda, semuanya mengandung karbohidrat. Karbohidrat ini diserap tubuh lewat usus, kemudian menjadi glukosa. Glukosa merupakan sumber energi utama bagi sel tubuh di otot dan jaringan. Agar glukosa dapat melakukan fungsinya, butuh "teman" yang disebut insulin. Hormon insulin ini diproduksi oleh sel beta dalam kelenjar pankreas. Tiap kali makan, pankreas memberi respon dengan mengeluarkan insulin ke dalam aliran darah. Ibarat kunci, insulin membuka pintu sel agar glukosa masuk sehingga kadar glukosa dalam darah menjadi turun.

Glukosa darah adalah parameter untuk mengetahui penyakit diabetes melitus yang dahulunya dilakukan terhadap darah lengkap. Kadar glukosa darah dapat ditentukan dengan berbagai metode berdasarkan sifat glukosa yang dapat mereduksi ionion logam tertentu, atau dengan pengaruh enzim khusus untuk menghasilkan glukosa, yaitu enzim glukosa oksidase. Enzim glukosa oksidase merupakan senyawa yang mengubah glukosa menjadi asam glukonat. Glukosa darah dikatakan abnormal apabila kurang atau melebihi nilai rujukan. Nilai rujukan glukosa adalah pada rentang 60-110 mg/dl. Kadar gula darah yang terlalu tinggi dinamakan hiperglikemia. Kadar glukosa kurang dari normal dinamakan hipoglikemia. Dalam tubuh manusia glukosa yang telah diserap usus halus kemudian akan terdistribusi ke dalam semua sel tubuhperti nasi, mi, roti, semua yang berasal dari padi-padian, buah-buahan, umbi-umbian, melalui aliran darah.18 Sedangkan gula yang menumpuk banyak di dalam pembuluh darah akan membuat darah menjadi kental dan alirannya melambat, sehingga mengakibatkan gangguan pada pasokan oksigen yang dibawa oleh darah. Jaringan yang tidak mendapatkan pasokan oksigen akan menjadi lumpuh dan mati. Gejala seperti mati rasa, kesemutan dan nyeri kaki.

Komplikasi lainnya antara lain berupa luka yang sulit sembuh (gangren) dengan risiko amputasi, gagal ginjal, kebutaan, dan impoten. Sedangkan lemak yang menumpuk di pembuluh darah menyebabkan pengerasan arteri (arterioskleirosis), dengan resiko penderitanya kena stroke atau penyakit jantung koroner. Dengan demikian, gula darah dalam tubuh adalah cairan berupa darah yang mengandung gula dan dibutuhkan tubuh untuk sistem metabolism.

Gangguan Toleransi Glukosa adalah keadaan jika kadar gula darah diatas normal, tetapi tidak terlalu tinggi untuk didiagnosa sebagai diabetes. Indikasinya adalah kadar gula darah antara 115-140 mg/dl. Gejala diabetes umumnya tidak muncul. Penderitanya dapat sembuh dan gula darahnya bisa menjadi normal. Sebagian lagi tidak mengalami perubahan, berada diantara ambang normal dan tinggi, sedang sisanya sebanyak 25 persen berkembang menjadi diabetes. Penderita kelompok ini lebih beresiko mengalami tekanan darah dan kadar kolesterol yang tinggi, yang dalam jangka panjang berakibat pada penyakit jantung koroner. ${ }^{20}$ Maka, gangguan glukosa yang terjadi pada tubuh salah satunya adalah diabetes.

Hipertensi atau tekanan darah tinggi adalah penyakit umum di kalangan lansia. Bahkan menurut National Heart, Lung, dan Blood Institute, orang-orang paruh baya berisiko hingga $90 \%$ mengalami hipertensi di masa senjanya nanti. Untungnya, ada berbagai cara sederhana untuk mengelola hipertensi pada lansia. 
Tekanan darah normal untuk kebanyakan orang dewasa berkisar di antara 120/80 mmHg. Namun, tekanan darah bukan sebuah kondisi yang menetap alias mandek. Tekanan darah bisa bervariasi setiap waktu tergantung dari banyak hal, mulai dari aktivitas apa yang Anda lakukan saat ini, makanan yang Anda makan, waktu pengukurannya, hingga usia. Tekanan darah lansia bisa terus berubah-ubah dan tidak dapat diprediksi dengan baik. Kadang, seorang lansia bisa memiliki tekanan darah rendah kemudian melonjak tinggi hanya diselingi beberapa saat. Sayangnya, alasan pergantian tekanan darah naik-turun secara cepat ini belum diketahui jelas apa penyebabnya.

Penyakit hipertensi pada lansia akan meningkatkan risiko terserang stroke di kemudian hari. Kondisi ini juga meningkatkan peluang Anda untuk mengalami kerusakan ginjal, penyakit jantung, dan banyak masalah kesehatan serius lainnya apabila Anda tidak bisa mengelola tekanan darah dengan baik. Oleh karena itu, banyak dokter sekarang menetapkan kisaran tensi 140/90 $\mathrm{mmHg}$ untuk orang yang lebih tua. Untuk membantu mencapai target ini, dokter bisa meresepkan obat tekanan darah yang mulai digunakan perlahan dan meningkat secara bertahap. Ini dilakukan untuk menghindari reaksi penurunan tekanan darah mendadak (hipotensi). Penurunan tekanan darah drastis bisa sangat berbahaya bagi lansia. Kondisi ini membuat mereka sering mengalami pusing, tubuh goyah, dan sensasi ingin pingsan yang bisa menyebabkan mereka rentan jatuh. Tulang lansia sudah mengalami pengeroposan dan penipisan, sehingga jatuh bisa menyebabkan patah tulang atau cedera serius lainnya. Berbagai cara mengelola hipertensi pada lansia diantaranya adalah mempertahankan tekanan darah tetap stabil dengan berbagai cara sederhana. Salah satu prinsip utama mengendalikan hipertensi pada lansia adalah melakukan perubahan gaya hidup. Usia tua bukan berarti terlambat untuk mengelola gaya hidup sehat agar terhindar dari tekanan darah tinggi dan komplikasinya.

Kolesterol membantu tubuh memproduksi vitamin D, sejumlah hormon, dan asam empedu untuk mencerna lemak. Kolesterol dalam kadar yang sesuai sebenarnya dibutuhkan oleh tubuh dalam membantu membangun sel-sel baru agar tubuh bisa tetap berfungsi secara normal. Selain dari itu, kolesterol juga dibutuhkan untuk proses pencernaan, produksi hormon, dan membentuk vitamin D. Jika kadar kolesterol terlalu tinggi, maka hal tersebut berbahaya bagi tubuh karena akan menyebabkan berbagai penyakit dan komplikasi. Di dalam darah, kolesterol dibawa oleh protein. Gabungan keduanya disebut dengan lipoprotein. Dua jenis utama lipoprotein adalah lipoprotein dengan kepadatan rendah (LDL) yang biasa disebut dengan kolesterol jahat dan lipoprotein dengan kepadatan tinggi (HDL) yang biasa disebut dengan kolesterol baik. Tugas LDL adalah mengangkut kolesterol dari organ hati ke sel-sel yang membutuhkan. Namun jika jumlah kolesterol tersebut melebihi kebutuhan, maka dapat mengendap pada dinding-dinding arteri dan menyebabkan penyakit.
Sementara itu, HDL bertugas untuk mengangkut kolesterol kembali ke dalam organ hati, sebagai kebalikan dari LDL. Dalam hati, kolesterol akan dihancurkan atau dikeluarkan oleh tubuh melalui feses atau kotoran.

Kadar koletesterol dalam darah yang disarankan untuk setiap orang bervariasi. Tergantung tiap orang apakah memiliki risiko lebih tinggi atau lebih rendah untuk bisa terkena penyakit pembuluh arteri. Sementara itu, pemeriksaan terkait kadar atau jumlah kolesterol dalam darah bisa diukur dengan melalui tes darah. Pemeriksaan kadar kolesterol dalam darah sebaiknya dilakukan jika mengalami gejala kelebihan berat badan, tekanan darah tinggi, mengidap diabetes, atau memiliki penyakit lainnya yang bisa saja meningkatkan kadar kolesterol. Jika terdapat keluarga dekat yang mengidap penyakit akibat kolesterol, atau ada keluarga dekat yang memiliki riwayat kardiovaskular pada usia dini, maka diagnosis terhadap kadar kolesterol sangat dianjurkan. Bagi mereka yang pernah terdiagnosis memiliki penyakit jantung koroner, stroke ringan, atau penyakit arteri perifer, disarankan melakukan pemeriksaan ini juga.

Risiko pengidap juga meningkat jika dia mengidap hipertensi, diabetes, atau memiliki keluarga yang mengidap penyakit jantung atau stroke. Kondisi genetik (keturunan) yang disebut dengan familial hypercholesterolaemia juga bisa menyebabkan kolesterol tinggi pada seseorang. Meskipun sudah menjaga pola makan dan mengonsumsi makanan sehat, tetapi kadar kolesterol pengidap kondisi ini akan tetap tinggi. Jika tingkat kolesterol dalam darah melampaui kadar normal, maka kondisi ini disebut sebagai hiperkolesterolemia atau kolesterol tinggi. Kondisi kolesterol tinggi dapat meningkatkan risiko penyakit serius. Kolesterol sendiri adalah senyawa lemak berlilin yang sebagian besar diproduksi pada organ hati dan sebagaian lainnya didapatkan dari makanan. Umumnya, serangan jantung dan stroke merupakan penyakit yang mengintai pengidap kolesterol tinggi yang diakibatkan adanya pengendapan kolesterol berlebihan pada pembuluh darah. Berdasarkan laporan dari WHO pada tahun 2011, sekitar 35 persen persen penduduk Indonesia diperkirakan memiliki kadar kolesterol lebih tinggi dari batas normal untuk kesehatan. Hal ini menunjukan bahwa sepertiga penduduk Indonesia berisiko tinggi terkena penyakit arteri. Mengonsumsi makanan dengan kandungan kolesterol tinggi atau kurang olahraga juga bisa menyebabkan kelebihan kolesterol, Namun, faktor keturunan juga bisa menjadi pemicu dari kolesterol.

Penyakit asam urat merupakan kondisi yang bisa menyebabkan gejala nyeri yang tak tertahankan, pembengkakan, serta adanya rasa panas di area persendian. Semua sendi di tubuh berisiko terkena asam urat, tetapi sendi yang paling sering terserang adalah jari tangan, lutut, pergelangan kaki, dan jari kaki. Umumnya, penyakit asam urat dapat lebih mudah menyerang laki- laki, khususnya mereka yang berusia di atas 30 tahun. Pada wanita, penyakit asam urat ini dapat muncul setelah terkena menopause. Rasa sakit yang dialami pengidap asam urat, dapat 
berlangsung selama rentang waktu 3-10 hari dengan perkembangan gejala yang begitu cepat dalam beberapa jam pertama. Sering kali orang salah kaprah dan menyamakan penyakit asam urat dengan rematik. Padahal, rematik adalah istilah yang menggambarkan rasa sakit pada persendian atau otot yang mengalami peradangan.

Terdapat beberapa faktor yang dapat memicu naiknya kadar asam urat dalam darah seseorang, antara lain memiliki keluarga yang mengidap asam urat, baru saja mengalami cedera atau pembedahan, gemar konsumsi makanan dengan kandungan purin tinggi, seperti daging merah, jeroan hewan, dan beberapa jenis hidangan laut (misalnya teri, sarden, kerang, atau tuna), gemar konsumsi minuman beralkohol dan minuman tinggi gula, kerap menggunakan obat, seperti diuretik, ciclosporin, dan beberapa obat kemoterapi. Memiliki kondisi medis tertentu, misalnya diabetes, gangguan sindrom metabolik, penyakit jantung, penyakit ginjal, penyakit tiroid, kolesterol tinggi, leukemia, anemia, sleep apnea, hipertensi, dan obesitas.

Berikut ini adalah faktor yang menjadi penyebab datangnya penyakit asam urat, antara lain makanan yang berzat purin tinggi yang dikonsumsi, seperti jeroan hewan, hidangan laut dan daging merah, banyak mengonsumsi minuman dengan gula tinggi dan minuman beralkohol, menggunakan obat-obatan dengan jenis tertentu, seperti aspirin, obat penghambat enzim, sislosporin, dan obat-obatan kemoterapi, mempunyai riwayat penyakit asam urat pada anggota keluarga.

Terdapat banyak gejala penyakit asam urat yang umum terjadi, antara lain: sendi mendadak terasa sangat sakit, ksulitan untuk berjalan akibar sakit yang mengganggu, khususnya di malam hari, nyeri akan berkembang dengan cepat dalam beberapa jam dan disertai nyeri hebat, pembengkakan, rasa panas, serta muncul warna kemerahan pada kulit sendi. Saat gejala mereda dan bengkak pun mengempis, tetapi kulit di sekitar sendi yang terkena akan tampak bersisik, terkelupas dan terasa gatal. Meski gejala penyakit ini bisa mereda dengan sendirinya, harus tetap dilakukan pengobatan untuk mencegah risiko kambuh dengan tingkat gejala yang meningkat. Untuk memastikan apakah gejala tertentu merupakan indikasi penyakit asam urat atau bukan, dokter akan melakukan beberapa langkah diagnosis. Dokter mungkin akan melakukan beberapa hal, seperti menanyakan riwayat penyakit pasien, seberapa sering gejala muncul, dan memeriksa lokasi sendi yang sakit.

Terdapat juga pemeriksaan lanjutan yang akan dilakukan untuk memastikan diagnosis, antara lain tes darah, tes urine, tes cairan sendi dan tes pencitraan. Tes Darah. Tes darah ditujukan untuk mengukur kadar asam urat dan kreatinin dalam darah. Mereka yang mengidap asam urat memiliki kreatinin hingga $7 \mathrm{mg} / \mathrm{dL}$. Namun, tes ini tidak selalu memastikan penyakit asam urat, karena beberapa orang diketahui memiliki kadar asam urat tinggi tetapi tidak menderita penyakit asam urat. Tes Urine 24 jam. Prosedur ini dilakukan dengan memeriksa kadar asam urat dalam urine yang dikeluarkan pasien selama 24 jam terakhir. Tes cairan sendi. Prosedur ini akan mengambil cairan sinovial pada sendi yang terasa sakit, kemudian akan diperiksa di bawah mikroskop. Tes Pencitraan. Pemeriksaan foto Rontgen akan dilakukan guna mengetahui penyebab radang pada sendi. Sementara itu, USG juga bisa dilakukan untuk mendeteksi kristal asam urat pada sendi.

Pada asam urat, biasanya terdapa dua jenis pengobatan. Karena pengobatan yang dilakukan memiliki dua sasaran utama yakni untuk meringankan gejala asam urat dan mencegah serangan kembali terjadi. Pengobatan asam urat yang bisa diterapkan untuk meringankan gejala asam urat adalah dengan menempelkan kantong atau kain berisi es pada bagian sendi yang sakit. Atau konsumsilah obat pereda sakit dan obat-obatan golongan steroid. Sementara untuk mencegah asam urat kambuh bisa dilakukan dengan mengonsumsi obat penurun kadar asam urat. Dengan menjaga perilaku dan menghindari kebiasaan pemicu asam urat serta rutin mengonsumsi obat terbukti ampuh menurunkan kadar asam urat.

\section{METODE}

Jenis penelitian ini adalah observasional analitik dengan pendekatan cross-sectional. Penelitian dilakukan di Posyandu lansia di desa Talok, sejak bulan Mei - Agustus 2019 terhadap lansia dengan rentang usia 45-80 sebanyak 70 orang dengan teknik sampling simple random sampling. Variabel penelitian ini adalah kadar gula darah, tekanan darah tinggi, asam urat, dan kolesterol. Teknik pengumpulan data dilakukan secara primer dan sekunder. Data primer adalah data yang diperoleh secara langsung yaitu kadar gula darah sewaktu (GDS), tekanan darah sewaktu, kolesterol dan asam urat dan diperoleh dari pemeriksaan CGU. Data sekunder adalah data yang diperoleh secara tidak langsung yaitu data lansia pada masing-masing posyandu. Analisis data dilakukan dengan menggunakan program SPSS for Windows versi 17.0. Data dianalisis secara statistik dengan proses sebagai berikut: analisis univariat bertujuan untuk mendeskripsikan karakteristik responden dan variabel penelitian. Data-data variabel penelitian dalam bentuk kategori dideskripsikan dalam prosentase dan data-data variabel penelitian dalam bentuk numerik dideskr.ipsikan dalam n, mean dan standar deviasi.

\section{HASIL DANPEMBAHASAN}

Hasil wawancara, observasi, dokumentasi dan pemeriksaan kesehatan. Karekteristik responden penelitian adalah jenis kelamin Frekuensi Laki-laki 21 dan Perempuan 59 sehingga jumlah responden adalah 70. Dapat diketahui bahwa sebagian besar responden dalam penelitian ini adalah laki-laki yaitu sebesar $20,2 \%$, dan responden perempuan sebesar $79,8 \%$. Hasil pemeriksaan tekanan darah menunjuukan bahwa $20 \%$ responden memiliki kecenderungan hipertensi, sedangkan untuk asam urat $30 \%$ responden memiliki kecenderungan asam urat dan kolesterol tinggi sehingga menjaga pola makan mejadi hal sangat penting. Sebagian besar responden dewasa mederita 
diabetes mellitus disebabkan oleh 2 faktor pola konsumsi makanan yang tinggi gula dan keturunan. Hanya sebagian kecil responden yang melakukan terapi insulin terhadap kadar gula darah.

Dari 70 responden yang menjadi sampel terdapat beberapa yang sudah memiliki keturunan kadar gula darah tinggi hal tersebut didukung dengan pola konsumsi makan yang tidak terkontrol menyebabkan memilki karad gula darah yang tinggi (melebihi batas normal) d. Variabel penelitian 4) Data numerik Tabel 2. Data kadar gula darah Kadar GDS N 203 Mean 124,75 Stdr.Deviasi 73,64 Minimum 56 Maksimum 510 Kadar gula darah dipeoleh dari pemeriksaan GCU pada kadar gula daah sewaktu. Dapat disimpulkan bahwa rata-rata nilai nilai GDS dalam penelitian ini masih dalam kategori normal yaitu 124,75 \pm 73,64 mg/dl. 5) Data kategori Tabel 3 . Kategori kadar gula darah Kategori Kadar gula darah Frekuensi \% Hiperglikemia 48 23,6 Normal 155 76,4 Total 203100 Berdasarkan tabel 3 dapat disimpulkan bahwa dari 203 lansia, sebanyak 23,6 \% memiliki kadar gula darah sewaktu lebih dari normal atau hiperglikemia. Kadar normal GDS adalah $<130 \mathrm{mg} / \mathrm{dl}$. HASIL DAN PEMBAHASAN Pada penelitian ini dari 203 lansia yang diperiksa terdapat sebanyak 23,6\% memiliki kadar gula darah sewaktu lebih dari normal atau hiperglikemia. Kadar normal GDS adalah $<130$ $\mathrm{mg} / \mathrm{dl}$. Hanya 2 orang yang sudah terkontrol dan sudah mendapatkan suntik insulin, selebihnya non insulin. Kadar gula darah yang melebihi normal dapat diartikan menderita Diabetes Mellitus. Diabetes Mellitus adalah kumpulan gejala yang timbul pada seseorang yang mengalami peningkatan kadar gula (glukosa) darah akibat kekurangan hormon insulin secara absolut atau relatif (Almatsier, 2007). Insulin yang dihasilkan oleh kelenjar pankreas yang terletak di lekukan usus dua belas jari sangat penting untuk menjaga keseimbangan kadar glukosa darah. Bila terjadi gangguan pada kerja insulin, baik secara kuantitas maupun kualitas, keseimbanagn tersebut akan terganggu sehingga kadar glukosa darah cenderung naik (Tjokroprawiro, 2006).

Diabetes mellitus merupakan suatu penyakit yang ditandai dengan kadar glukosa darah melebihi normal. Insulin yang dihasilkan oleh kelenjar pankreas sangat penting untuk menjaga keseimbangan kadar glukosa darah yaitu untuk orang normal (non diabetes) waktu puasa antara $60-120 \mathrm{mg} / \mathrm{dL}$ dan 2 jam sesudah makan dibawah $140 \mathrm{mg} / \mathrm{Dl}$ (Badawi, 2009). Klasifikasi Diabetes Mellitus yaitu Diabetes Melitus Tipe I, Diabetes Melitus Tipe II, Diabetes Melitus Tipe Gestasional, dan Diabetes Mellitus The 8 th University Research Colloquium $2018 \quad$ Universitas Muhammadiyah Purwokerto 588 tipe lainnya. Jenis Diabetes Melitus yang paling banyak diderita adalah Diabetes Melitus Tipe II. Diabetes Melitus Tipe II adalah penyakit gangguan metabolik yang ditandai oleh kenaikan gula darah akibat penurunan sekresi insulin oleh sel beta pankreas dan atau gangguan fungsi insulin (Depkes, 2005). Dalam proses metabolisme insulin memegang peranan yang sangat penting yaitu bertugas memasukkan glukosa dalam sel, untuk selanjutnya dapat digunakan sebagai sumber energi (Suyono, 2004). Insulin adalah suatu zat atau hormon yang dikeluarkan oleh sel beta pankreas. Bila insulin tidak ada, maka glukosa akan tetap berada dalam pembuluh darah yang artinya kadarnya di dalam darah meningkat. Dalam keadaan seperti ini badan akan lemah karena tidak ada sumber energi didalam sel (Suyono, 2004).

Pada penderita Diabetes Mellitus tipe II, jumlah insulin normal tetapi reseptor (penangkap) insulin di permukaan sel kurang, sehingga glukosa yang masuk ke dalam sel sedikit. Akibatnya sel kekurangan bahan bakar (glukosa) dan kadar glukosa dalam darah meningkat (Paradigta, 2009). Faktor lain seperti kurangnya aktifitas fisik, makanan mengandung lemak, juga dinyatakan berkaitan dengan perkembangan terjadinya kegemukan dan resistensi insulin (Indraswari, 2010). Umumnya Diabetes Mellitus disebabkan oleh rusaknya sebagian kecil atau sebagian besar dari sel-sel beta dari pulau-pulau langerhans pada pankreas yang berfungsi menghasilkan insulin, akibatnya terjadi kerusakan insulin. Menurut Hasdianah (2012), ada beberapa faktor pemicu yang menyebabkan terjadinya diabetes antara lain : Pola makan, obesitas (kegemukan), faktor genetis, bahan-bahan kimia dan obat-obatan, penyakit dan infeksi pada pankreas, kurangnya aktifitas fisik dan usia lanjut. Salah satu faktor penyebab diabetes mellitus pada penelitian ini adalah faktor usia lanjut. Pengobatan DM dapat dilakukan denganrajin berolahraga, melakukan pengaturan diet dan terapi obat. Terapi obat disini dapat secara farmakologi maupun non farmakologi.

\section{SIMPULAN DAN SARAN}

Simpulan Berdasarkan hasil penelitian dan pembahasan yang telah diuraikan peneliti maka secara umum dapat disimpulkan bahwa terdapat $23,6 \%$ sampel yang megalami hiperglikemia atau mengalami Diabetes Mellitus. Hasil pemeriksaan tekanan darah menunjuukan bahwa $20 \%$ responden memiliki kecenderungan hipertensi, sedangkan untuk asam urat $30 \%$ responden memiliki kecenderungan asam urat dan kolesterol tinggi sehingga menjaga pola makan mejadi hal sangat penting.

Saran yang dapat diberikan setelah dilakukan kegiatan pengabdian Masyarakat ini adalah: 1) Kader posyandu perlu mengaplikasikan pengetahuan dan keterampilan yang telah didapatkan selama pelatihan. 2) Tim pengabdian masyarakat perlu melanjutkan program dan kegiatan yang belum tuntas. 3) Tim pengabdian masyarakat memberikan pendampingan dan evaluasi secara berkala terkait pemanfaatan media promosi kesehatan dan peralatan pengolah herbal.

\section{DAFTAR PUSTAKA}

[1]. Arisyi S.P. 2011. pengaruh pemberian decota daun lidah buaya(Aloe vera $L$ ) terhadap penurunan kadar glukosa darah tikus wistar yang diberi beban glukosa. 
[2]. Arryska Ayu P. 2008. Uji Efek Penurunan Kadar Glukosa Darah Ekstrak Etanol 70 \% Buah Jambu Biji (Psidium Guajava L.) Pada Kelinci Jantan Lokal. Fakultas Farmasi Universitas Muhammadiyah Surakarta Surakarta.

[3]. Jelantik Darma Putra. 2014.Pengaruh pemberian ekstrak kering daun sukun (artocarpus) terhadap kadar glukosa darah pada tikus putih diabetes mellitus. Program studi ilmu keperawatan fakultas kedokteran universitas udayana.

[4]. Lanny lingga. 2010. Bebas diabetes tipe II tanpa obat. Jakarta. Pt agromedika pustaka.

[5]. Misnadiarly. 2006.Diabetes mellitus. Jakarta. Pustaka popular obor.

[6]. Mistral. 2008. 3 jenis melawan diabetes melitus. Jakarta. Puspa swara anggota IKAPI. 